\title{
"Ultimate Skepsis": Nietzsche on Truth as a Regime of Interpretation ${ }^{2}$
}

\author{
Patrick $_{\text {Wotling }}$
}

(Translated by Paul Carls)

In a letter addressed to Chanut on March 31, 1649, Descartes pronounces a strange opinion: "The knowledge of truth is like the health of the soul: once a man possesses it, he thinks no more of it" (Descartes, "Letter" 370). If error is characterized by the author of Metaphysical Meditations by the fact that "we do not recognize it as a case of error" ("Fifth Set" 245), if it is characterized by its ability to conceal itself, to deceive, to pass itself off as truth, then would the truth not be that which, barely recognized, tends to be forgotten?

Of course, Descartes' is perhaps just a witty formulation, a bit of irony that he uses on a number of occasions. But if we are to take what he says seriously, does it not indicate that there might be a secret antagonism between truth and thought? This would thereby indicate a problem for the philosopher and for our understanding of the philosophical mission-a mission related to philosophy's traditional claim of being the rigorous use of thought, of conscious thought, of thought that is clear and distinct, that is in action and at work, that exposes the reasons for things to broad daylight, that gives itself the task of defusing aporia and of resolving the apparent tensions that plunge us into uncertainty. While Descartes' expression is perhaps without consequence in his work, Nietzsche, quite unexpectedly, would be able to take it word for word as his own: he would indeed subscribe to it completely. It is the meaning of this surprising

\footnotetext{
${ }^{1}$ GS §265; 219. Abbreviations to Nietzsche's published works will be as follows: BGE (Beyond Good and Evil), BT (The Birth of Tragedy), GM (On the Genealogy of Morals), GS (Gay Science), TI (Twilight of the Idols), followed by section and page numbers. References to Nietzsche's unpublished notes are from the Kritische Studienausgabe (KSA). Abbreviations are written as follows: KSA 11, 26[15]; 153-where 11 refers to the KSA volume, 26[15] to the fragment, and 153 indicates the page number. Translations of Nietzsche's unpublished notes are Paul Carls', and the original in German is given in the footnotes.

2 This paper was originally published as “'L'ultime scepticisme': La vérité comme régime d'interprétation," in P. Wotling, La philosophie de l'esprit libre: Introduction à Nietzsche, Paris, Flammarion, 2008.
} 
congruence and its consequences as to how we understand the philosophical project that I will examine in the following pages.

What is it, then, about this perplexing link between truth and forgetting that Descartes brings to our attention, and why would it be possible for the author of Beyond Good and Evil, in this one instance at least, to consider himself Cartesian? The main reason that Nietzsche would be able to subscribe to this idea has to do with the fact that forgetting does not mean that the thing thought, the thing represented in our mind in the moment just prior, disappears. On the contrary, apart from the common psychological understanding of forgetting, which is identified with a superficial distraction or eclipse of consciousness, there exists, as Nietzsche indicates, a different kind of forgetting: to no longer think about something that one possesses also constitutes the specific mark of internalization. In other words, the unconsciousness and the fact of forgetting show themselves, on a fundamental level, to be much more the results of the effective presence of what is thought, of the thought in action, and especially of the perfect mastery of what is thought. Forgetting, as the result of the work of internalization, therefore appears as a sign of strength: only that which has been made unconscious is truly active, or, as one could say, is real, and from then on it plays its role in regulating an individual's thoughts and actions with a perfect regulatory certainty, a certainty that conscious thought, which makes use of demonstrative argumentation and inferences and is so often subject to hesitation and error, almost never attains. This functional certainty is for Nietzsche characteristic of instincts, or of drives. It indicates a perfect functioning, an act that is completed without one even having to think about it. And as the turn of phrase in the letter to Chanut indicates, that is exactly why we no longer think about it, precisely at the moment when the thought is at its strongest. There are innumerable examples of this phenomenon in Nietzsche's work, but others have drawn attention to this paradox in dazzling ways. Perhaps the most striking example is the Duke of Guermantes, from Marcel Proust's In Search of Lost Time: through his mannerisms and even his choice of words, he aspires to embody an ancien régime character. But to the extent that he consciously makes an effort to play the role, he fails: he falls victim to over-acting, excess, and an exaggerated, artificial, almost caricatural archaism, thereby loosing all credibility. However, once he stops thinking about it, he instantaneously falls back into the character he was trying to impersonate. ${ }^{3}$

Thus, as regards interiorized processes, conscious thought, far from being an effective guide, constitutes an obstacle. Now this issue might very well apply to the way truths are put into action, since truth is

3 "Very untrue to the old world when he tried thus to assume its manner, the Duke then relapsed into it unconsciously" (Proust 483). 
not fully truth, is not an absolute certainty, unless it is interiorized. As a consequence, we are forced to recognize that we come across a curious split between truth and rationality. Instincts - which with drives and affects make up the infrarational ${ }^{4}$ — are what make the rational possible in a derivative way, as Nietzsche shows in his genealogical reduction of conscious thought to drive-based activity. We thus face a paradox: truth, in its fullest sense, the very idea of truth, would be that which we no longer even attempt to truly justify through reason.

The relevance of truth is self-evident, or rather it is treated as if it were self-evident in a certain sense, to such an extent that its evidence is untouchable, almost sacred. We no longer think about the reasons why we admit the legitimacy of the idea of truth. But if the idea of truth and its consequences for the deployment of thought are indeed commanded by this logic, it places the philosopher-that individual who seeks to be radical and intransigent in the exercise of reflection and questioning, who claims to be ready to sacrifice everything (opinions, beliefs, personal interests) for truth-before a fearful moral dilemma. Isn't this defense of truth precisely the sign that the philosopher is in the same situation as the average person when confronting truth, i.e. that the philosopher possesses no special privilege in this regard? The difference, however, is that if the situation is merely surprising in the case of the non-philosopher, in the case of the philosopher it becomes a scandal because it is precisely the philosopher who promises to explain everything rationally through thought. This situation is a perfect example of a contradiction that Nietzsche so frequently points out as going unnoticed by philosophers. As it happens, the position of philosophers reveals itself to be contradictory in the sense that the goal they are working towards invalidates the means they use to attain it. Philosophers seek truth, but if truth is not what it is except as the result of a process of internalization, conscious thought, with its demonstrative arsenal, is incapable of legitimizing it. Here, once again, Nietzsche denounces the amusing self-deception ${ }^{5}$ that is so often seen in philosophy: the concrete practice of philosophers betrays the theory of their action.

In other words, what we recognize in philosophers is an unwavering defense of the idea of truth, but most definitely not an irreproachable exercise of radical thought. The proof lies in the fact that the demand for justification is never applied to truth itself. Indeed the validity of the search for truth is accepted on principle: "Consider on this question both the earliest and most recent philosophers: they are all

\footnotetext{
4 "Infrarational" designates the unconscious processes that Nietzsche refers to when he speaks of drives, instincts, or affects. As concerns philosophy, according to Nietzsche all rational thought derives from these processes and thus possesses no autonomy.

${ }^{5}$ Nietzsche sometimes uses the term Selbstüberlistung, particularly as concerns Socrates.
} 
oblivious of how much the will to truth itself first requires justification; here there is a lacuna in every philosophy" (GM III §24; 152). ${ }^{6}$

In this way, because our thinking no longer pursues a radical line of questioning when dealing with the question of truth, and provided that one is serious about completing one's search for truth, a troubling series of difficulties and questions without answers arises. In other words, the presuppositions of the philosophical practice become apparent, a practice that nevertheless considers itself to be radical and free of all presuppositions. Let us briefly review the main questions — of which there are five - that philosophy does not bother to ask and that it perhaps is even required to avoid for the sake of its own survival.

To begin, how is it possible to justify the opposition between true and false? With this opposition our entire dichotomous and exclusive way of representing the whole of reality-in sum, dualism, that fundamental element which upon closer inspection is shown to inform our way of thinking - is put into place. But is dualism really the framework through which all thought must pass? Does a contradictory, exclusive division, one that would condition the entirety of the world, and that would out of necessity make things black or white, true or false, good or bad, sensory or intelligible, really need to exist?

To point out these kinds of lacunae is to open Pandora's box, since this first question leads to many others. Supposing, for example, that the dichotomous division of reality (which would be a kind of fundamental ontological structure) is legitimate, it would remain to be shown why, between true and false, it is in the end truth that should be privileged. Here again, according to Nietzsche (and on this point, one could certainly find common ground between him and Hume), with philosophers things are lived and felt much more than they are thought. This is because, in effect, it is possible to recognize a real, instantaneous loathing for error, a sort of instinctive horror, which through its sheer intensity hides itself from theoretical interrogation. But once again, this attitude does not conform to the philosophical ideal that is asserted and defended, against all odds, by every philosopher up until the present:

The will to truth which will still tempt us to many a venture, that famous truthfulness of which all philosophers so far have spoken with respect - what questions has this will to truth not laid before us! What strange, wicked, questionable questions! ... What in us really wants "truth"? ... Suppose we want truth: why not rather

\footnotetext{
${ }^{6}$ See also BGE $\S 1$ especially, and GS $\S 347$ : "that impetuous demand for certainty ... The demand that one wants by all means that something should be firm (while on account of the ardor of this demand one is easier and more negligent about the demonstration of this certainty)" (p. 288).
} 
untruth? and uncertainty? even ignorance? ... And though it scarcely seems credible, it finally almost seems to us as if the problem had never even been put so far-as if we were the first to see it, fix it with our eyes, and risk it. (BGE §1; 9)

The third element has to do with the presence of a strange affective conditioning: in philosophy, truth is experienced as a passion, it is loved and worshipped as a goddess. Yet this attitude contrasts quite oddly with the supposed ideal of rationality! Once again, there is a discrepancy between how philosophy is conceived of in theory and how it is practiced concretely, especially considering that this passion for truth is often taken to a high degree of fanaticism. As a consequence, the entire understanding of philosophy as the search for truth becomes problematic.

A fifth point is often highlighted by Nietzsche. This point concerns how philosophers have predetermined the idea of truth in such a way that it seems to meet neither the requirement of neutrality nor that of objectivity. To the contrary, we surprisingly find the presence of a sort of prior agreement: "Also behind actual friends of truth, philosophers, an intentionality of which they are often unconscious is at work: they want from the beginning a certain 'truth,' one crafted in a particular way - and often enough, in following their path to their 'truth,' they have revealed their most intimate needs" (KSA 11, 26[15]; 153). ${ }^{7}$ In this way, as Twilight of the Idols makes clear, philosophers resemble saints much more than they do disinterested explorers. Would they not be, in the end, "another kind of saint," aware beforehand of the exclusive goal they wish to attain? "[T] heir whole craft is such that they admit only certain truths ... They know what they must prove; in this they are practical. They recognize each other by their agreement about 'the truths.' 'Thou shalt not lie': in other words, beware, my dear philosopher, of telling the truth" (TI, "Skirmishes of an Untimely Man” §42; 546).

However, these omissions in the questioning process surprisingly allow a certain activity normally presented as true philosophy to function quite efficiently, except that in so doing it fulfills a task that is different from the one announced. Yet these omissions are nonetheless at odds with the very idea of philosophy and implicitly indicate problems that need to be confronted. Provided that we try to rectify this attitude that is forgetful of its principles and try to bring about, in all of its rigor and probity, the demand for philosophy as a radical form of questioning, we will inevitably be led to address these omissions while contemplating the following questions: What if truth were a particular kind of error? What if what is

7 “Auch hinter den eigentlichen Freunden der Wahrheit, den Philosophen arbeitet eine ihnen oft unbewußte Absichtlichkeit: sie wollen von vorn herein eine gewisse, so und so beschaffene ,Wahrheit' - und oft genug haben sie ihre innersten Bedürfnisse verrathen, indem sie ihren Weg zu ihrer ,Wahrheit' giengen." 
false, illusory, or deceitful were preferable to what is true? What if truth were the product of affectivity and not rationality? What if philosophy, finally understood in its authenticity, were not a search for truth, but a way of dealing with error (which is to say a search for certain truths)? What if, finally, one were forced to admit that truth always comes in second, that it is nothing more than a response to a certain kind of demand, a demand whose nature is still undetermined, but that might have something to do with demands of a practical nature as well as with specific needs? Would the philosopher, as a particular type of person whose search for truth is taken as disinterested and universal, actually express the needs of a particular form of life? In sum, who needs truth? Who needs to believe in the existence of truth? Who needs, even, to claim to believe in its existence?

These questions manifestly raise suspicions about the fragility of the idea of truth, which is revealed as being incapable of producing for itself the rational legitimation that it nevertheless demands from all other thoughts before it agrees to accept them as valid. The suspicion is this: that truth is in some way at odds with its own idea, that it is in contradiction with itself, in sum, that truth is an error. That the very idea of truth is suspect consequently extends the suspicion to the processes by which this supposed norm derives particular truths and verifies their acceptability while simultaneously eliminating thoughts that do not conform to these procedures, i.e. the thoughts that fail the test of convincing procedures and demonstrative techniques. If truth is a false idea, the theoretical rules that administer proof can no longer have the same validity as they do normally. What has been demonstrated can thus no longer be considered true, just as what has been refuted is not necessarily false. Confronted with this surprise, our deepest distrust is awakened: the feeling that the curtain is being pulled back from our eyes calls forth a new form of skepticism, perhaps even the most devastating kind - the "ultimate skepsis," as in fact Nietzsche will say: "Ultimate skepsis: What are man's truths ultimately? Merely his irrefutable errors" (GS §265; 219).

Truth is error, truth is that species of falsehood that is able to conceal its nature and to pass itself off as the negation of what it is. Does this dramatic conclusion thus lead to the pure and simple end of the questioning, and to the relegation of philosophical ambition to the numerous illusions that humanity, over time, has deluded itself with? The originality of Nietzsche's thought lies precisely in his rejection of such a proposition, and it is here without doubt that the rigor of his analysis is most spectacular and subtle: such an attitude of rejection would in fact only be justified if the dualistic opposition between truth and falsehood, as well as the absolute advantage given to truth, maintained their relevance. But Nietzsche is not guilty of the inconsistency he detects among his adversaries; on the contrary, the collapse of these two theses revives the 
interrogation, and far from heralding the end of philosophy, it finally offers the opportunity to liberate and invigorate philosophy's demand. It is thus at this point that the courage that Nietzsche argues is among the true philosopher's foremost virtues becomes indispensable. Henceforth, courage will determine our ability to overcome the disarray and distress that come from being confronted with this disaster, which takes away everything we had in theoretical terms believed in up to that point, all that was most sacred and that seemed safe from any possible challenge. Courage will determine our ability to fight against the almost irresistible feeling of despondency and emptiness, of the collapse of norms and points of reference - a feeling that leaves us distraught and that can arouse both paralysis and devastation on the one hand, and revolt and furor of destruction on the other, which are two twin forms of nihilism.

Is it not, thus, unavoidable to lament and to proclaim that nothing is true, that existence is a game in which we have been deceived from the beginning, as if a cruel god were having fun at the spectacle of our despair? It all depends on the meaning, and even more on the affective coloration that is attached to these statements-it is still too early to answer this question clearly, and taking one's time is another philosophical virtue. At this point, Nietzsche is well within reason to affirm without restriction: "there is no 'truth'." (KSA 12, 2[108]; 114) But this condemnation of the idea of truth (as philosophers ordinarily understand it) is not his final thought. There are still many other issues to think through.

In order to clarify the status of the false idea that is truth and to understand the meaning of the displacement that Nietzsche carries out, it is necessary to reflect on one of the parameters that plays a determinate role as to how truth is raised to the rank of a norm. Namely, it is a question of how truth is experienced as a constraint, emphasized as it is in such strong terms by Descartes, once again, who identifies in the awareness of being "compelled to accept" a proposition, the distinctive mark of obviousness or of judgment "inferred from quite evident principles" (Descartes, "Sixth Set" 296). What good is it to claim, even if at the end of the most rigorous intellectual path, that truth is an illusion, if at the same time I am not able to abstain intellectually from receiving it as valid, nor to prevent it from imposing itself on my thought? Does the invincible impossibility to think otherwise not save the traditional philosophical position in extremis? On the contrary, according to Nietzsche who interrogates the type of constraint that the identification of a truth effectively produces, this impossibility reveals the exact nature of truth and confirms its disqualification by disclosing the type of logic it is integrated into. To be

8 "Es gibt keine ,Wahrheit'." See also KSA 13, 14[122]; 303: "The concept of truth is nonsensical." ("Der Begriff, Wahrheit' ist widersinnig.") 
sure, there is a constraint, one that is particularly noticeable in the case of the obvious truth as identified by Descartes, and the mind indeed experiences the impossibility of acquiescing immediately to the contrary judgment. But it is not a question of a metaphysical impossibility, which is sufficient in demonstrating beyond any doubt the emptiness of the opposite opinion. The test of invincibility, to which the mind makes reference in proclaiming the indisputable validity of the judgment in question, might indicate much more the limits of understanding that circumscribe the abilities inherent to that particular mind, and thus reveal the mark of a specific culture of which it is a product. In other words, the feeling of constraint is never an indication of a universal absolute. The existence of cultures that do not make truth a supreme norm testifies to this fact. A good example of this is the fundamentally artistic tragic culture of the Greeks, which, on the contrary, emphasizes creation, the ability to give form to new interpretations, and is wary of the cult of objectivity. ${ }^{9}$

By establishing the fact that what is irrefutable is not what is true, Nietzsche makes apparent that indisputability can and should be interpreted on even more fundamental grounds. To resist the efforts of theoretical contestation is a sign of something wholly other than theoretical validity, and the sign that we stand on grounds where the logic of conscious rationality, with its arsenal made of demonstrative techniques and convincing procedures, is no longer efficient. In short, it is the sign that we stand on practical grounds and that we are dealing with a value, and not a simple representation derived from the realm of speculation and susceptible to truth and falsity. And the fundamental misstep of philosophy was exactly this: not to understand that truth is a value, not an essence.

In order to interpret this situation, it is necessary to return to the logic of becoming-unconscious, or of making-unconscious, which is the logic of incorporation. For Nietzsche, this is in general the logic of life itself: in this sense, life is the ordering of fundamental preferences that then process and sort through experience, looking for certain situations and arrangements while rejecting others. In other words, these fundamental preferences interpret reality in a particular way. A value, which is a translation of these preferences, is thus characterized by its practical action, or its imperative dimension, which is to say its functional reliability; the sorting through of experience, in order to be efficient, should operate in an instantaneous manner, without hesitation, and should thus be removed from consciousness and its deliberative procedures. A

\footnotetext{
${ }^{9}$ This involves a rejection of the preeminence of the idea of truth that is translated through the interpretation of the past in the form of myth and not in the form of historical annals (see BT §10).
} 
value is nothing other than an interpretation, but it is an incorporated interpretation, one that is assimilated into other fundamental preferences, which altogether result in instinctive activity, the totality of which forms what Nietzsche calls "the body." In sum, a value is an interiorized belief that is no longer thought about, and which, far from disappearing, exercises a formidable functional efficiency, and this for the following reason: "the strength of knowledge does not depend on its degree of truth but on its age, on the degree to which it has been incorporated, on its character as a condition of life" (GS $\$ 110 ; 169)$. In itself, truth is indeed one simple interpretation of reality among many other possibilities. Yet, in the context of our culture-which is deeply unaware of how Platonic it is - it is an interpretation that has been accorded a crushing dominance, and which for a long time has been incorporated and integrated into our system of drives, of which it is now a decisive part. We thus find, at the end of this detour and renewed exploration, the confirmation of what Descartes' formulation might suggest, namely the idea that there is a fundamental link between truth and forgetting, provided that the latter is understood as the sign of a perfect assimilation.

This authorizes Nietzsche to argue that truth is in fact incorporated error-moreover, all of reality is error, insofar as it is interpretation and it in no way offers an absolute norm. ${ }^{10}$ In this way we discover the necessity of illusion for life, and in certain cases of the illusion that presents itself as a truth and that creates strong belief in itself as such. Thus, truth is reduced to error: it is even defined as error, which is not a paradox if we realize that the realm of theory possesses no autonomy and depends entirely on the logic of axiology:

"Truth": according to my way of thinking this does not necessarily indicate the opposite of error, but in the most fundamental of cases only the way different errors are put in relation with each other; for example, one is older, deeper than the other, perhaps even ineradicable, insofar as a living being of our type would not be able to live without it; while other errors do not tyrannize us, in that way, as conditions for life, and in comparison to such "tyrants" can be eliminated and "refuted." A hypothesis that is irrefutablewhy should it for this reason alone be true? This sentence will perhaps outrage logicians, who determine their limits to be the limits of things: but long ago I already declared war against this logicians' optimism. (KSA 11, 38[4]; 598 $)^{11}$

\footnotetext{
${ }^{10}$ See, e.g., BGE $\$ 34:$ "Whatever philosophical standpoint one may adopt today, from every point of view the erroneousness of the world in which we think we live is the surest and firmest fact that we can lay eyes on" (p. 45).

11 “,Wahrheit': das bezeichnet innerhalb meiner Denkweise nicht nothwendig einen Gegensatz zum Irrthum, sondern in den grundsätzlichsten Fällen nur eine Stellung
} 
If reality is an interpretation, and is as such always error and illusion, does philosophy end in a situation of non-differentiation, in which it is impossible to establish the validity of one interpretation over another, or is it necessary to admit that a new criterion of distinction, one that replaces the irrelevant criterion of truth, is at work in the world of interpretations? Would there then exist differences between errors that can be called into question and others that resist such efforts, refutable errors and irrefutable errors, so to speak? Indeed, such is the central line of Nietzsche's thought. What is undeniable can also stem from the realm of error-but it is not an error like the others. That something must be irrefutable is indicative of the constraints imposed by an interpretative demand rooted in the specific values of a culture, an interpretative demand that has become the very condition for the continuation of life for those living creatures whose existence is organized by it. It is thus inevitably the result of a long relationship, of a practice and habit exercised over a very long period of time-truth is never young. To this is added this second trait, amply highlighted by Nietzsche, that if truth is interpretation, and thus illusory and erroneous, the fact that it possesses a long history indicates that we are not dealing with any ordinary type of illusion, but illusion that is efficacious, error that has stood the test of time, and demonstrated through lived experience its ability to organize a community's existence. There is thus nothing more limited than our perception of truth: " $\mathrm{Nb}$. The first limit for all 'sense of truth' is - for all less developed creatures as well-what does not serve their preservation is of no concern to them. The second: the way of viewing a thing that is preferred is the way that is the most useful to them, and only gradually, through heredity, is it incorporated. Humanity also has by no means changed this yet" (KSA $11,26[58] ; 162-3) .{ }^{12}$ In a certain sense, truth is an old falsehood. In other words, it is old because it has survived the diversity of experiences it has encountered, and it is

verschiedener Irrthümer zu einander: etwa daß der eine älter, tiefer als der andere ist, vielleicht sogar unausrottbar, insofern ein organisches Wesen unserer Art nicht ohne ihn leben könnte; während andere Irrthümer uns nicht dergestalt als Lebensbedingungen tyrannisiren, vielmehr, gemessen an solchen ,Tyrannen', beseitigt und ,widerlegt' werden können. Eine Annahme, die unwiderlegbar ist, - warum sollte sie deßhalb schon wahr sein? Dieser Satz empört vielleicht die Logiker, welche ihre Gränzen als Gränzen der Dinge ansetzen: aber diesem Logiker-Optimismus habe ich schon lange den Krieg erklärt." See also the following text: "Truth is the type of error, without which a certain species of living creatures would not be able to live. Its value for life determines the final decision." ("Wahrheit ist die Art von Irrthum, ohne welche eine bestimmte Art von lebendigen Wesen nicht leben könnte. Der Werth für das Leben entscheidet zuletzt." (KSA 11, 34[253]; 506)

12 “NB. Die erste Grenze alles, Sinnes für Wahrheit' ist - auch für alle niederen belebten Geschöpfe - was nicht ihrer Erhaltung dient, geht sie nichts an. Die zweite: die Art und Weise ein Ding zu betrachten, welche ihnen am nützlichsten ist, wird vorgezogen und allmählich erst, durch Vererbung, einverleibt. Dies ist auch durch den Menschen noch keineswegs anders geworden." 
something that we are henceforth used to and that no longer surprises usthus the difficulty of questioning it. Nietzsche often insists on old age as an essential factor in determining what is "true," as for example in the poem found in the Song of Prince Vogelfrei entitled "In the South," which offers one of the most original expressions of this idea:

Up North-embarrassing to tell-

I loved a creepy ancient belle:

The name of this old hag was Truth.

$(\text { GS p. 357) })^{13}$

Nietzsche provides numerous examples of old errors that have preserved a form of life and that we are obliged to experience as truths, to such an extent that we confidently claim to have constructed a science that takes them as object of study. Such is the case, notably, with the idea of causality, which follows very precisely the logic of incorporation that I mentioned above: 'NB. The a priori 'truths' that are best believed are for me - hypotheses until further notice, for example the law of causality, very well-used habits of belief, so incorporated, that to no longer believe in them would condemn the race to its demise. But are they, because of this, truths? What a conclusion! As if truth were proved by the fact that humanity continues to exist!" (KSA 11, 26[12]; 152-3) ${ }^{14}$

More fundamentally, it is the concepts we use to structure our interpretation of reality that fall under the same scrutiny, beginning with the ideas of permanence or duration, or even with the very idea of "thing," the belief in the fact that reality is a universe of stable objects existing durably and of their own accord. All these errors have become truths for us, as another posthumous text indicates:

In itself it would be possible that the preservation of a species requires especially fundamental errors, and not "fundamental truths." It is possible, for example, to imagine a form of existence in which knowledge itself would be impossible, because there is a

\footnotetext{
${ }^{13}$ But the logic of Nietzsche's thought does not end there. He makes clear that it is indispensible for the philosopher to envisage the consequences of these axiological and interpretative choices over time. Only a study of the evolution of a culture over a very long period of time in its history is able to show whether or not these values are beneficial or harmful in the end. In the latter case, which most certainly applies to cultures who privilege the value "truth," such a study will allow one to observe the movement of the self-destruction, or self-negation, of values that are not in harmony with nature and the demands of reality (i.e. its interpretative nature).

14 “NB. Die bestgeglaubten a priorischen, Wahrheiten' sind für mich - Annahmen bis auf Weiteres z.B. das Gesetz der Causalität sehr gut eingeübte Gewöhnungen des Glaubens, so einverleibt, daß nicht daran glauben das Geschlecht zu Grunde richten würde. Aber sind es deswegen Wahrheiten? Welcher Schluß! Als ob die Wahrheit damit bewiesen würde, daß der Mensch bestehn bleibt!'
} 
contradiction between absolute flux and knowledge: in such a world a living creature would first have to believe in things, in duration, etc. in order to be able to exist: error would be its condition of existence. This is perhaps the case. (KSA 11, 26[58]; $163)^{15}$

This discovery finally allows us to return to the question of dualism, which, as we have seen, also structures our interpretations and constitutes a value for the type of human we embody, the particular form of life that we represent, and the culture that we express. Thus, it constitutes a necessity in the organization of our existence; but this is not the case in every culture or in every form of life. The Dionysian, for example, does not obey the logic of this dualistic partition. To understand reality according to contradictory oppositions is a matter of axiological preferences, not of objective knowledge. This implies that truth is defined by a logic of configuration internal to the life of values, not by an essential difference regarding error: "Truth does not indicate the opposite of error, but the positioning of certain errors with respect to other errors, for example that they are older, more deeply incorporated, that we do not know how to live without them, etc." (KSA 11, 34[247]; 503). ${ }^{16}$

Far from constituting the norm of all thought, which nevertheless represented philosophy's fundamental presupposition up until now, truth in fact designates a particular regime of interpretation. This is to say that truth reveals itself as a particular form of the will to power, as is indicated in a posthumous text that condenses the collection of conclusions to which Nietzsche's investigation leads: 'the 'will to truth' develops in service of the 'will to power': more precisely, its actual task is to help a certain type of untruth attain victory and permanence, to take an entire assemblage of falsehoods as the basis for the preservation of a certain type of living being" (KSA 11, 43[1]; 699). ${ }^{17}$ But, as such, the idea that humanity's relationship with reality is constantly guided by an artistic instinct, one that is as inventive as it is unconscious, is also confirmed: to create new

15 "An sich wäre es möglich, daß zur Erhaltung des Lebenden gerade GrundIrrthümer nöthig wären, und nicht, Grund-Wahrheiten'. Es könnte z.B. ein Dasein gedacht werden, in welchem Erkennen selber unmöglich wäre, weil ein Widerspruch zwischen absolut Flüssigem und der Erkenntniß besteht: in einer solchen Welt müßte ein lebendes Geschöpf erst an Dinge, an Dauer usw. glauben, um existiren zu können: der Irrthum wäre seine Existenz-Bedingung. Vielleicht ist es so."

16 "Wahrheit bezeichnet nicht einen Gegensatz zum Irrthum, sondern die Stellung gewisser Irrthümer zu anderen Irrthümern, etwa daß sie älter, tiefer einverleibt sind, daß wir ohne sie nicht zu leben wissen und dergleichen."

17 “[D]er , Wille zur Wahrheit' entwickelt sich im Dienste des , Willens zur Macht': genau gesehen ist seine eigentliche Aufgabe, einer bestimmten Art von Unwahrheit zum Siege und zur Dauer zu verhelfen, ein zusammenhängendes Ganze von Fälschungen als Basis für die Erhaltung einer bestimmten Art des Lebendigen zu nehmen." 
forms and establish relations and links is above all the process whereby truths are established. To establish fundamental relations between sequences of reality, to transform into "things" the drive-based processes ${ }^{18}$ that constitute reality, to invent for this purpose identity, duration, essence, absolute oppositions - in other words to interpret, which is to say to deform, while nevertheless imposing on oneself the implacable rigor of a particular rule - this is the process that covers the position, or the disposition, of certain errors with respect to other errors that Nietzsche discusses. Truth is art, and not speculation, but an art that possesses the particularity of denying itself as such! It is an art that does not want to be art, and that stubbornly resists presenting itself as what it is. Indeed, there is in truth something like an internal negation, a sort of contradiction or self-hatred, and a stubborn effort to deny reality as a game of illusions. This is why, according to Nietzsche, the position of truth as a value inevitably leads to its own self-destruction, plunging into nihilism the type of person who makes truth an object of veneration.

Perhaps the most disconcerting aspect of this thought that so radically upsets our comfortable intellectual reflexes is this: despite the radicalism of his critique, Nietzsche does not purely and simply dismiss the idea of truth. Here, a final development regarding the completion of Nietzsche's reinterpretation is needed, since even deposed, truth has a role to play in the philosophical project, on the condition that our way of thinking about it changes in light of the discoveries that have been made.

"From the moment faith in the God of the ascetic ideal is denied, a new problem arises: that of the value of truth. The will to truth requires a critique - let us thus define our own task - the value of truth must for once be experimentally called into question" (GM III §24; 153). If the authentic logic of thought is axiological and not theoretical, if as a consequence truth is nothing other than interpretation, it is advisable to interrogate it as a value and to draw out the consequences for the pursuit of philosophical activity, which can no longer be identified with the will to truth. There are three fundamental implications that characterize the modification of the philosophical project and the redefinition of the philosopher's work.

It would be superficial to ignore truth or to maintain its disqualification on the grounds that it is only interpretation; refutation is never a goal for Nietzsche. Rather, it is necessary to treat truth as a particular interpretation, and from this perspective, to treat it as one would any other interpretation, which would allow for the disclosing of its meaning and formative logic. This is because the philosopher faces an enigma: what conditions are required for an interpretation of reality characterized as truth to appear and establish itself? "Truth" denotes a

${ }^{18}$ On how drive-based processes constitute reality, see footnote 20 on "processuality." 
type of interpretation, or more precisely, a type of adherence produced by certain interpretations. Why, at a certain stage of its history and cultural conditioning, would a type of living being feel the imperious need to interpret reality according to truth?

The genealogy of truth, used in this way, leads to the identification of needs that seek to be satisfied in this original shaping of reality. At least two tendencies that the philosopher will then need to interrogate and interpret can be identified-granted, of course, that the two can indeed be distinguished. First, there is a moral (and not at all an epistemological) preference that $\$ 344$ of The Gay Science studies in detail: the will to truth expresses a visceral repulsion for deception, no matter what its object or who its victim is. At the same time, there is a psychological preference, namely the equally visceral rejection of all that is variable, instable, and ungraspable, especially when dealing with doubt and uncertainty in theoretical form. Indeed, the desire for what is true is fear hidden in theoretical disguise: "The will to truth and certainty arises out of fear in uncertainty" (KSA 11, 26[301]; 231). ${ }^{19}$ This being a decisive feature, the desire for truth allows one, or should allow, to escape a feeling of unease due to uncertainty, which thereby implies that this uneasiness is felt as unbearable.

This is a decidedly strange situation... What could be the meaning of these hidden preferences that stubbornly express themselves through what seems, at first sight, to be such a disinterested valorization of truth? How is it possible that a living being, at a certain stage of its history, comes to experience as an aggression the very conditions of the reality of which it is a part? In this horrified refusal of processuality, ${ }^{20}$ the psychologist will identify a need related to the compensation of a weakness; it is a will to power, still, but one that is characterized by a dramatic dwindling of the means at its disposal to master the rich complexity of reality: "How much one needs a faith in order to flourish, how much that is 'firm' and that one does not wish to be shaken because

19 "Wille zur Wahrheit und Gewißheit entspringen aus Furcht in der Ungewißheit." See also the following posthumous fragment, "All this longing for the immutable is the result of discontent." ("Alles dies Verlangen nach Unvergänglichem ist die Folge der Unzufriedenheit" [KSA 10, 7[150]; 292]).

${ }^{20}$ It is important to avoid the term, often used in philosophy, of "becoming," a term that Nietzsche in fact rarely uses. This is why I use the word "processuality." "Becoming" is in fact not a neutral term: it refers to a concept elaborated within the context of idealist thought that Nietzsche is against, and as such it is governed by a dualistic logic that opposes becoming to "being," the former having no claims to reality. As such, it is an opposition that leads becoming to be condemned and used in a pejorative way. It is necessary, then, to go beyond these prejudices in order to understand all of reality as an ensemble of processes, which Nietzsche designates most often by the terms of drive, instinct, affect, or even interpretation. 
one clings to it, that is a measure of the degree of one's strength (or, to put the point more clearly, of one's weakness). ... For this is how man is: An article of faith could be refuted before him a thousand times - if he needed it, he would consider it 'true' again and again" (GS §347; 287). The philosopher-physician will prolong this analysis and perhaps see in it the irruption of a fundamental hostility towards this reality, which has become a source of suffering and now calls mediately for its own elimination. To interrogate the status of truth thereby undoubtedly leads to the most profound enigma that Nietzsche's thought confronts, namely the mystery that is life's ability to turn against itself: "Of course: here we must raise the question of truthfulness: granted that we live as a result of error, what then can the 'will to truth' be? Would it not have to be a 'will to death'?Would the endeavours of philosophers and scientists perhaps be a symptom of a declining, dying life, a kind of weariness towards life itself? Quaeritur: and about this one could truly think deeply" (KSA 11, 40[39]; 649). ${ }^{21}$ In the form that we know it to have taken since Plato, would philosophy not thus reveal itself as a desperate protest against reality, with truth being a technique used in the service of death?

It is thus essential to reform philosophical activity: that is the second consequence of the inquiry that began by locating truth's paradoxes. Indeed, after the real status of what used to be presented as a supreme criterion of thought is identified, the philosopher's objective can no longer be to search for truth: it will more than ever become an attempt at discovering truths. This is precisely because its task consists in elucidating the life of values, and because these "truths," blind to their own status, represent fundamental value-judgments that are shielded from questioning and whose veneration has been imposed onto communities, thereby governing different cultures. To try to identify the truths of each culture and to evaluate them would mean to assess, as a philosopherphysician, the nature of the influence that they and the values that underpin them have exerted on the life of the peoples who have imposed

\footnotetext{
21 "Freilich: wir müssen hier das Problem der Wahrhaftigkeit aufwerfen: gesetzt, wir leben in Folge des Irrthums, was kann denn da der, Wille zur Wahrheit' sein? Sollte er nicht ein ,Wille zum Tode' sein müssen? - Wäre das Bestreben der Philosophen und wissenschaftlichen Menschen vielleicht ein Symptom entartenden absterbenden Lebens, eine Art Lebens-Überdruß des Lebens selber? Quaeritur: und man könnte hier wirklich nachdenklich werden." GS $\S 344$ argues the same point: "will to truth' does not mean 'I will not allow myself to be deceived' but - there is no alternative - 'I will not deceive, not even myself'; and with that we stand on moral ground. For you only have to ask yourself carefully, 'Why do you not want to deceive?' especially if it should seem - and it does seem!- as if life aimed at semblance, meaning error, deception, simulation, delusion, self-delusion ... Charitably interpreted, such a resolve might perhaps be a quixotism, a minor slightly mad enthusiasm; but it might also be something more serious, namely, a principle that is hostile to life and destructive.- 'Will to truth' - that might be a concealed will to death." (p. 281-2)
} 
them on themselves. This point is particularly emphasised in Beyond Good and Evil: "Those philosophical laborers after the noble model of Kant and Hegel have to determine and press into formulas, whether in the realm of logic or political (moral) thought or art, some great data of valuationsthat is, former positings of values, creations of value which have become dominant and are for a time called "truths" (BGE §211; 136). What is more (since the preceding task is incumbent upon philosophical labourers), the requirement that makes the task of philosophy unique is be to create new "truths"- or, in other words, new values - that in the case of contemporary Europe are formulated with an eye towards the urgent necessity of combating nihilism.

The task that emerges from this investigation confirms the Nietzschean concern for maintaining the idea of philosophy, which is much more a matter of finally bringing it about in its authentic form than it is of discarding it. But the success of this project supposes to reform beforehand the way in which the philosopher is understood. That constitutes the final point that needs to be explained. A remark in the Genealogy of Morals will set us onto the path of this requirement, which an intriguing reference to Epicureanism outlines: "They are far from being free spirits: for they still have faith in truth" (GM III §24; 150). Such is what Nietzsche affirms about philosophers as they have existed since Socrates: he underlines with fervour the fact that despite their ideal, they still give their allegiance to an authority that is a belief-and, what is worse, a belief that is not identified as such. It is thus the emancipation from the tyranny of truth that opens up the possibility for the philosopher to become a genuinely free spirit. For the philosopher, the cardinal virtue is indeed independence (see, e.g., GS §98). To know how to guard oneself from the fanaticism of truth, which has tyrannized the practice of philosophy up to the present, will be its first function. This will be the prerequisite for finally being able to think the artistic nature of reality, which is to say it will allow one to have the courage to confront reality's simultaneously problematic, elusive, disconcerting, and terrible character. In sum, freedom of the mind will be characterized by an original form of skepticism, but one that will no longer simply be the "theoretical" skepticism proper to the history of philosophy.

The most important instinct that makes someone a philosopher, in this perspective, will indeed be what Nietzsche calls the Epicurean instinct of one who is fond of enigmas. As an example of this instinct's incarnation, Nietzsche mentions Stendhal, "this odd epicurean and question mark of a man who was France's last great psychologist" (BGE $\S 254 ; 194)$. It is no coincidence that Nietzsche also turns to Stendhal at the beginning of Beyond Good and Evil when looking for an adequate description of a philosopher (see BGE §39). For Nietzsche, "Epicurean" does not have the same meaning as it does in common language 
(particularly when the word is associated with hedonism), but rather indicates a mix of curiosity and skepticism that refuses to accept just any explanation or truth. To enjoy the enigmatic character of reality and the game it plays to constantly resist our mind's efforts to master it, particularly our use of logical schemes or philosophical theories; to not want truth at any price, an attitude that is not very demanding and that would lead one to be satisfied with the first "truth" that comes along, provided that it prevents us from experiencing change and uncertainty; to have the courage to know that sometimes uncertainty is preferable to any "truth" whatsoever: such are the principal requirements permitting us to recognize the figure of philosophical radicality. That is why, to conclude, it is necessary to say about philosophy what The Birth of Tragedy already stated about science: "There would be no science if it were concerned only with that one nude goddess and with nothing else" (BT §15; 95). To be an artistic Epicurus, something Socrates was never able to be, rather than a friend of truth: this is the gamble that Nietzsche makes - the beautiful risk, perhaps, that he accepts to take-when he draws the portrait of the philosopher of the free spirit.

\section{Works Cited}

Descartes, René. "Author's Replies to the Fifth Set of Objections." The Philosophical Writings of Descartes. Vol. II. Trans. by J. Cottingham, R. Stoothoff, D. Murdoch, and A. Kenny. Cambridge: Cambridge University Press, 1991.

-. "Author's Replies to the Sixth Set of Objections." The Philosophical Writings of Descartes. Vol. II. Trans. by J. Cottingham, R. Stoothoff, D. Murdoch, and A. Kenny. Cambridge: Cambridge University Press, 1991.

—. "Letter to Chanut, 31 March 1649." The Philosophical Writings of Descartes. Vol. III The Correspondence. Trans. by J. Cottingham, R. Stoothoff, D. Murdoch, and A. Kenny. Cambridge: Cambridge University Press, 1991.

NIETZSCHE, Friedrich. Beyond Good and Evil. Trans. by W. Kaufmann. New York: Vintage Books, 1966.

-. On the Genealogy of Morals. Trans. by W. Kaufmann and R.J. Hollingdale. New York: Vintage Books, 1967.

—. The Birth of Tragedy. Trans. by W. Kaufmann. New York: Vintage Books, 1967. 
—. The Gay Science. Trans. by W. Kaufmann. New York: Vintage Books, 1974.

-. Twilight of the Idols. In The Portable Nietzsche. Ed. and trans. by W. Kaufmann. New York: Penguin Books, 1976.

-. Sämtliche Werke. Kritische Studienausgabe (KSA). Ed. by G. Colli and M. Montinari, 15 vols. Munich: DTV; Berlin/New York: de Gruyter, 1999 ( $2^{\text {nd }}$ ed.).

Proust, Marcel. The Guermantes Way. Trans. by D.J. Enright, T. Kilmartin, C.K. Scott Moncrieff. London: Vintage, 1996. Vol. 3 of In Search of Lost Time. 6 vols. 